\title{
Investigation the Factors Affecting Customer's Post-Purchase Perceived Risk in Luxury Products (Case Study: Apple Mobile Phone Buyers)
}

\author{
Investigação dos fatores que afetam o risco percebido pós-compra do cliente \\ em produtos de luxo (estudo de caso: compradores de celulares da Apple)
}

\author{
Seyyed Alireza Modarresi \\ Amin Asadollahi"
}

\begin{abstract}
In the present study, we examined the factors affecting customer's post-purchase perceived risk in luxury products. The research method is applied in terms of purpose and it is descriptive in terms of survey type. The statistical population of this study is students of Islamic Azad University of Qazvin Branch using Apple mobile phones. In this study the sampling method is convenience sampling in which questionnaires are distributed among the sample. In the present study sample size is determined as variables and structural equation method is used for data analysis. The sample size is 384 persons. Questionnaire was used to collect data and structural equation technique was used for data analysis. The results also showed that financial, visual, hedonic and operational risks are the dimensions of perceived post-purchase risk in luxury goods.
\end{abstract}

Keywords: Financial risk; Visual risk; Hedonic risk; Operational risk

\section{Resumo}

No presente estudo, examinamos os fatores que afetam o risco percebido pós-compra do cliente em produtos de luxo. O método de pesquisa é aplicado em termos de finalidade e é descritivo em termos de tipo de pesquisa. A população estatística deste estudo é de estudantes da Universidade Islâmica Azad de Qazvin Branch usando telefones móveis da Apple. Neste estudo, o método de amostragem é a amostragem de conveniência, na qual os questionários são distribuídos entre a amostra. No presente estudo, o tamanho da amostra é determinado como variáveis e o método da equação estrutural é utilizado para a análise dos dados.

\footnotetext{
' Department of Business Management (Marketing Trend), North Tehran Branch, Islamic Azad University, Tehran, Iran - modarresi@aftermail.ir "PhD, Marketing Management, Science and Research Branch Islamic Azad University, Tehran, Iran amin_asadollahee@yahoo.com
} 
O tamanho da amostra é de 384 pessoas. Utilizou-se questionário para coleta de dados e técnica de equação estrutural para análise dos dados. Os resultados também mostraram que os riscos financeiros, visuais, hedônicos e operacionais são as dimensões do risco pós-compra percebido em bens de luxo.

Palavras-chave: Risco financeiro; Risco visual; Risco hedônico; Risco operacional 


\section{Introduction}

Today, the uncertainties and risks associated with various activities have created a risk-free environment for a variety of transactions and exchanges. When we study purchasing behavior as voluntary behavior, there is no doubt that the outcome of a purchase decision is satisfaction, so positive results are expected. To prevent this, the present study examines the purchase risks. The trend of luxury booms and luxury goods is growing sharply in today market. Luxury products tend to offer unique benefits in the form of enjoy and symbolic value. Consumers of these products are seriously trying to identify their social capital by classifying and membership as part of a specific group that has unique interests and high quality of service (YANG \& MATTILA, 2012).

Management researchers believe that perceived risk is a multidimensional structure. Post-purchase perceived risk refers to the probable distribution of uncertainty results after purchase. To better understand this, it is necessary to determine the difference between risk and uncertainty, because they are often used interchangeably. Economists believe that risk involves both positive and negative outcomes. In fact, concurrent risk can have benefits or losses and introduce reference points. When people identify certain aspects of an option as benefits or risks but cannot rely on it, they are in a state of uncertainty. Thus, unlike the risk approach that highlights the status of decision making in management, the uncertainty approach is involved in the process of reaching the final decision from an economic perspective (CHANG \& KO, 2017).

Apple is undoubtedly one of the most thoughtful and smart phone makers in the world. The company's meticulous planning to promote the use of iPhones has been admirable, and for years the company has been competing with dozens of powerful and large Android product companies alone. Today, iPhone phones are classified as luxury products.

Given the definition of perceived risk before purchasing luxury products, the risks for iPhone buyers are problematic. Because it is difficult for them to find a rational justification and this creates a great deal of uncertainty. The use of this brand is also hedonic and symbolic, but their practical aspects can also be explored. This uncertainty is due to the 
increased variety and dimensions of perceived risks, including operational risk, financial risk, hedonic risk, and visual risk.

Finally, luxury products often require multiple or continuous interactions with customers and this completely removes the uncertainty about the initial handling of the products.

Based on the model presented in CHANG et al. (2017) research, post-purchase perceived risk can be considered as components of operational risk, financial risk, hedonic risk, and visual risk. Therefore, the present study aimed to investigate the post-purchase perceived risk of these components among Apple mobile phone buyers was performed.

\section{Theoretical FOUNDATIONS and research background}

\subsection{Theoretical framework and conceptual model of research}

Perceived post-purchase risk refers to the likelihood of post-purchase uncertainty results being distributed (GREWAL et al., 2007).

To clarify the concept of risk, we need to understand the difference between the terms "risk" and "uncertainty" because the two terms are often used in interactions in service management and consumer behavior.

Likewise, OKADA (2005) showed that consumers valued the final alternative higher than when the utility and hedonic options were presented separately. When the two utility and hedonic alternatives were presented simultaneously, the utility alternative was preferred over the hedonic alternative. Thus, although the set of each alternative was equal in the two choices, consumers showed different consumption patterns. In other words, consumers exhibited risk-taking behavior in a separate choice position because they preferred entertaining products.

In the context of customer management and consumer behavior, the concept of luxury has not been fully explored. SEKORA (1977) defines luxury products as objects that the consumer does not need. 
To address this phenomenon, TYNAN et al. (2010) suggest that the concepts of luxury and non-luxury are based on the same, so where the finalization of judgments between ordinary and luxury products begin depends on consumer judgment.

Likewise, ALLERES (1990) has in mind the concept of existing luxury situations. Specifically, with the understanding of consumer mental availability of the product, luxury can be transformed into (a) inaccessible products (high quality luxury goods) into a target market and (b) luxury items available for market sales.

Given this, it is assumed that the amount of product that exhibits the mentioned characteristics determines the level of luxury (TYNAN et al., 2010). Now the question is what are some of the post-purchase risks in luxury products? To address this question, we conducted an extensive review and considered several specific domains when re-purchasing luxury services.

Researchers of customer management and consumer behavior often represent the concept of perceived risk as a multidimensional structure (BOSHOFF, 2002; CHANG, \&TSENG, 2011; CHEN, 2013; SUN, 2014; LAROCHE ET AL., 2004; TSIROS \& HEILMAN., 2005). For example, Laroche et al. (2004) pointed out that product instability increases consumer risk.

Luxury researchers have identified a number of influential determinants of luxury consumption. For example, based on an approach to maximizing value, CHEN AND PENG (2014) proposed three degrees of luxury hotel service that affect traditional hotels.

Three functional values (eg, quality and superiority), empirical (eg, uniqueness and rarity) and symbolic (eg, sensitivity) are valued. Identifying specific features of value-added lux services, LEE \& HWANG (2011) proposed five French restaurant features such as food and service (functional), price (financial), and emotions and physical environments (hedonic)

Such previously predicted values face a perceived risk to consumers that ultimately leads consumers to decide whether to buy luxury goods or services.

\subsection{Research Background}

CHANG AND KO (2017) conducted a study on post-purchase in luxury goods. 
In this study, they explained the concept of perceived post-purchase risk in luxury products and introduced it as a recognized psychological risk. The results of this study showed that the operational, financial, hedonic and visual risks of perceived risk dimensions were introduced after purchasing luxury products.

WEAVER AND RANVEER (2015), conducted a study on the impact of word of mouth marketing on service purchase decision making: risk assessment and power interaction of relationships and conflicts. The purpose of this article is to examine how to conceptualize perceived risk consisting of two types (outcome risk and psychological risk) on service purchase decision making. The results showed that perceived risk had a stronger effect on buying behavior than other variables.

SUN (2014) conducted a study aimed at filling this gap in the literature and examining the factors and consequences of understanding consumer risks for the service experience, hotel services. Results of a survey of Chinese consumers who received hotel services, more recently, and it has been shown firm-level and individual-level preconditions directly affect perceived risk. While psychological and social risks have a positive impact on word of mouth advertising. The perceived risk of using luxury hotels is not high.

CHIU et al. (2014) conducted a study on understanding customer repeated shopping goals in B2C E-commerce: the role of benefit value, delightful value and perceived risk. They said customer loyalty or repetitive shopping is critical to the revival and success of any store. In the research model, both utility value and hedonic value are hypotheses that affect the positive impact of repetitive purchasing. The perceived risk is but a hypothesis that negates the intention to buy a duplicate.

HEIDARZADEH et al. (2016) examined the impact of customer satisfaction, perceived confidence, perceived risk, and customer awareness on the willingness to buy a new product. Overall, the statistical results show a positive and significant effect of customer satisfaction, perceived confidence, customer awareness of the product (in the high awareness group) and perceived risk (in the low risk group) on the willingness to buy and there is a significant relationship between product awareness (in the low awareness group) and discounted (in the risk group) the willingness to buy. 
VARAMINI AND HEIDARZADEH KANZAI (2015) in a study entitled which aspects of perceived nutritional risk (psychological, functional, and physical) is more and which consumers are less interested in buying a new product? Statistical results generally show the highest percentage of psychological, functional and physical dimensions respectively in high risk conditions and high frequency of functional (taste), psychological (quality) and physical (health) dimensions respectively in low risk conditions. Therefore, it is generally recommended that food producers focus more on the psychological dimension or quality (than on other risk dimensions) to encourage their new products.

SAEEDA ARDAKANI AND JAHANBAZI (2015) investigated the impact of store image on customer intention to buy: trust and perceived risk as moderating variables.

The purpose of this study was to investigate the effect of customers' mental image of the store on their intention to buy with respect to the moderating role of trust and perceived risk, from October to late February 2013. The results of data analysis showed that the impact of customer trust on purchase intention is more than their perceived risk. Also, the impact of the type of products offered by the store on the customers' perceived trust, risk and intention to purchase is more than the effect of "promotions", "facilities", "services" and "store atmosphere" on these items.

SAYAHZADEH KAKHKI (2014) conducted a study to investigate the impact of perceived product quality, price and perceived risk on customer value and willingness to buy. The results show that it is very important to create a perceived value in the purchasing process. Specifically, high quality exhibitions are highly effective in packaging shelf space, product layout, and media use. In addition, it is recommended that minimizes purchase risk, which plays an important role in the consumer decision-making process by ensuring the quality of post-purchase service.

SAEEDI et al. (2014) conducted a study to investigate the impact of perceived risk on intention to use mobile banking services. The impact of perceived risk and its dimensions including financial risk, operational risk, temporal risk, psychological risk and privacy risk on the intention to use the bank's mobile services were tested; the findings indicate that all perceived risk dimensions examined in this study influence the intention to use the bank's mobile services. 
FEIZ AND ISMAILI (2011) examined the place of perceived trust and risk in predictive models of customer intention to buy in e-commerce. In this study, by considering previous researches, the most appropriate model is considered and its relationships are tested. Trust and perceived risk variables were identified as two important determinants of customer purchase intention.

\section{Research method}

The present study is applied with regard to the goal. Applied research examines theoretical constructs in contexts and practical situations. Since the present study examines the territory under investigation on a case-by-case basis among Apple mobile phone buyers, so the research is applied. The present study is from the point of view of the analytical or structural research approach. In this study, it was not possible to examine all sample members and the researcher seeks to reach a plausible level of certainty by examining a part of the community. The research is a descriptive case study in terms of research direction. Finally, it should be noted that the research is correlative in nature and in terms of field data collection, because the researcher is present in the community under study and will be collecting data to chart the relationships between variables.

\subsection{Population and sample size}

The statistical population of this study is students of Islamic Azad University of Qazvin Branch using Apple mobile phones. The sampling method in this study is convenience sampling in which questionnaires are distributed among the statistical sample. To determine the sample size since the variables in the present study were present. Structural equation method is used to analyze the data. The sample size is between 5 and 15 times the number of questionnaire items. Therefore, the researcher distributed 384 questionnaires among students.

(Continue...) 


\subsection{Data collection method and tools}

Since the research is a survey, survey method is used to collect research data. In addition to using the library method for data collection, field methods and more are needed to gather the required information. The data collection tool in this study is a questionnaire which is adopted from the questionnaire in CHANG AND KO (2017) article and consists of 4 dimensions and 26 indices and will be rated with 5 likert scale options.

\subsection{Validity of the questionnaire}

In the present study, construct validity by factor analysis using LISREL software is used to determine the validity of the research. If the factor loadings for the items were higher than 0.5 , then the questionnaire has validity.

\subsection{Reliability of the questionnaire}

Correlation coefficient was used to determine the reliability of the questionnaire. To determine the coefficient of this reliability, the questionnaire was delivered to 30 sample members in two separate times. Since the scores obtained by each test in the first run were similar to those in the second run, the questionnaire would have a test-retest reliability, to determine this reliability, the correlation coefficients between the two implementations will be calculated and Pearson correlation coefficients will be calculated as a test-retest reliability index, which indicates the reliability of the questionnaire. The results of calculating the correlation coefficient are described in the following table. Based on the results, the responses received were correlated at two different intervals and therefore the questionnaire is reliable.

Table 1 - Reliability survey results

\begin{tabular}{l|l|c|c|c|c}
\hline \multicolumn{2}{l|}{} & $\begin{array}{c}\text { Operational } \\
\text { risk }\end{array}$ & $\begin{array}{c}\text { Financial } \\
\text { risk }\end{array}$ & $\begin{array}{c}\text { Hedonic } \\
\text { risk }\end{array}$ & $\begin{array}{c}\text { Visual } \\
\text { risk }\end{array}$ \\
\hline $\begin{array}{l}\text { Operational } \\
\text { risk }\end{array}$ & $\begin{array}{l}\text { Pearson } \\
\text { Correlation }\end{array}$ & $.901^{* *}$ & & & \\
\hline
\end{tabular}




\begin{tabular}{|c|c|c|c|c|c|}
\hline & $\begin{array}{ll}\text { Sig. } & (2- \\
\text { tailed }) & \end{array}$ & .000 & & & \\
\hline & $\mathrm{N}$ & 30 & & & \\
\hline \multirow{3}{*}{$\begin{array}{l}\text { Financial } \\
\text { risk }\end{array}$} & $\begin{array}{l}\text { Pearson } \\
\text { Correlation }\end{array}$ & & $.727^{\star \star}$ & & \\
\hline & $\begin{array}{ll}\text { Sig. } & (2- \\
\text { tailed) } & \end{array}$ & & .000 & & \\
\hline & $\mathrm{N}$ & & 30 & & \\
\hline \multirow{3}{*}{$\begin{array}{l}\text { Hedonic } \\
\text { risk }\end{array}$} & $\begin{array}{l}\text { Pearson } \\
\text { Correlation }\end{array}$ & & & $.761^{\star *}$ & \\
\hline & $\begin{array}{ll}\text { Sig. } & (2- \\
\text { tailed }) & \end{array}$ & & & .000 & \\
\hline & $\mathrm{N}$ & & & 30 & \\
\hline \multirow{3}{*}{ Visual risk } & $\begin{array}{l}\text { Pearson } \\
\text { Correlation }\end{array}$ & & & & $.733^{* *}$ \\
\hline & $\begin{array}{l}\text { Sig. } \\
\text { tailed) }\end{array}$ & & & & .000 \\
\hline & $\mathrm{N}$ & & & & 30 \\
\hline
\end{tabular}

\subsection{Data analysis methods and tools}

After extracting, sorting and analyzing the questionnaire data, demographic characteristics of statistical sample are presented in the form of tables and statistical charts using Excel software. Then, descriptive analysis of research variables including frequency of response, mean, mode and standard deviation is expressed. Finally, inferential data analysis is performed. For this purpose, the sample adequacy KMO test and the Bartlett test determine the suitability of the correlation. Next, the normality of the variables is determined by the Kolmogorov-Smirnov test. Then, confirmatory factor analysis test is used to evaluate the significance of items and finally, path analysis technique is used to measure the relationship between variables. It should be noted that the implementation of the structural equation technique is performed using LISREL software. Reliability, descriptive statistics, 
Kolmogorov-Smirnov KMO index and Bartlett's test are used by SPSS software. Based on the above, the conceptual model of research is designed as follows:

Figure 1 - Conceptual model of research

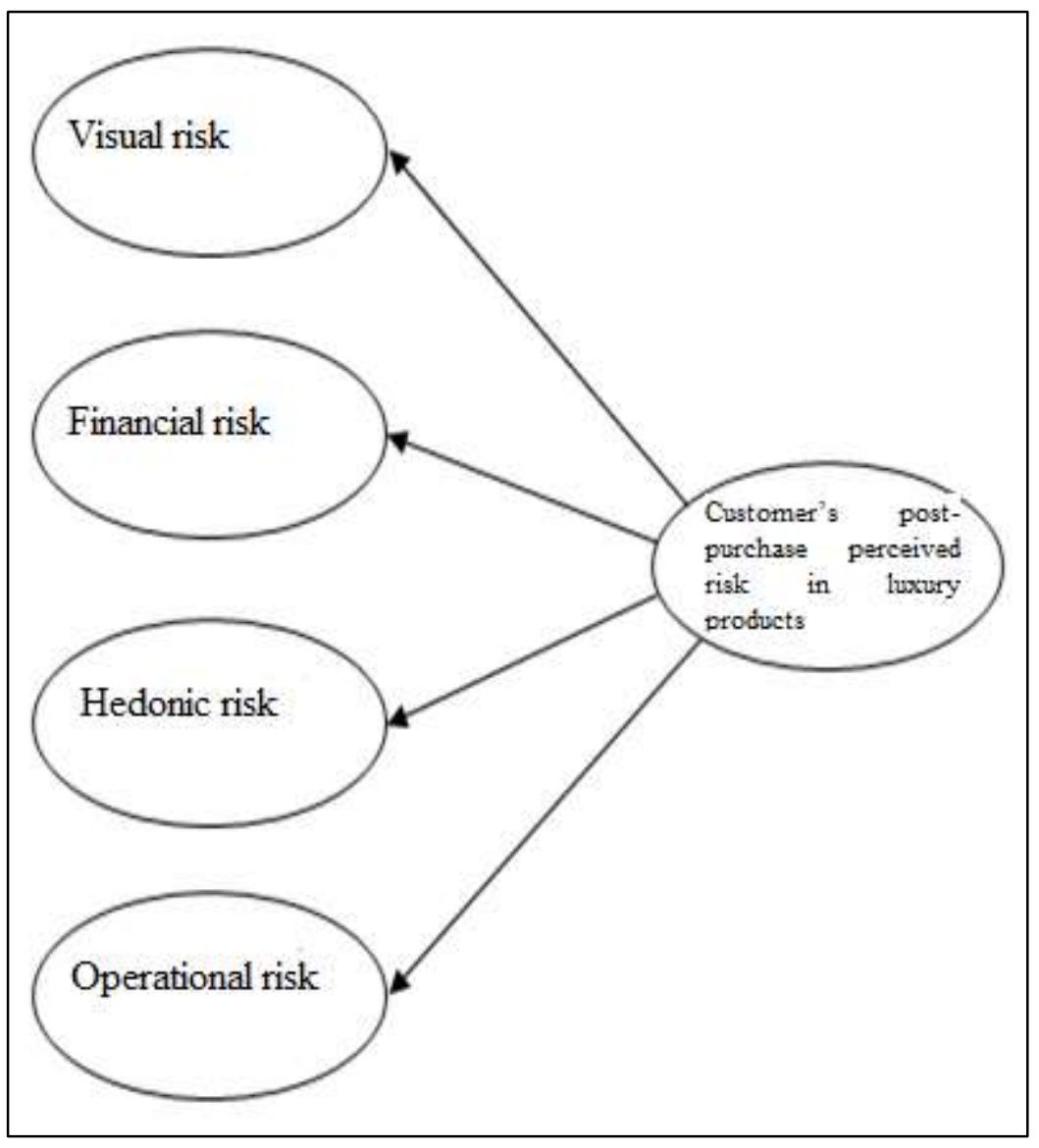

Source: Chang \& Ko (2017)

\section{Research findings}

\subsection{First section: Descriptive analysis}

\subsubsection{Demographic characteristics}

This section examines the demographic characteristics of the sample under study, including marital status and gender. The demographic characteristics of the sample under study are presented in tables and graphs.

Table 2 - Frequency of demographic variables 


\begin{tabular}{l|l|l|l}
\hline \multicolumn{2}{c|}{ Variables } & Number & Percentage \\
\hline \multirow{2}{*}{ Gender } & Male & 206 & 0.54 \\
\cline { 2 - 4 } & Female & 178 & 0.46 \\
\hline \multirow{2}{*}{$\begin{array}{l}\text { Marital } \\
\text { status }\end{array}$} & Single & 241 & 0.63 \\
\cline { 2 - 4 } & Married & 143 & 0.37 \\
\hline
\end{tabular}

The results show that most individuals are single and male.

\subsubsection{Descriptive analysis of research variables}

In this section, a table is drawn that presents the mean and standard deviation of each variable.

Table 3 - Descriptive statistics of the research variables

\begin{tabular}{l|c|c|c|c|c}
\hline \multicolumn{1}{c|}{ Variable } & Number & Minimum & Maximum & Average & $\begin{array}{c}\text { Standard } \\
\text { deviation }\end{array}$ \\
\hline Operational risk & 384 & 1.34 & 4.28 & 3.0111 & .51321 \\
\hline Financial risk & 384 & 1.76 & 4.38 & 3.0455 & .49123 \\
\hline Hedonic risk & 384 & 1.41 & 4.49 & 3.0022 & .51414 \\
\hline Visual risk & 384 & 1.67 & 4.27 & 2.9929 & .49346 \\
\hline
\end{tabular}

According to the results, the level of financial risk has a higher average than other variables, which implies that individuals have the highest level of risk among purchasing risks.

\subsection{Second section: Inferential analysis}

This section deals with inferential data analysis. For this purpose, the normality of the research variables is evaluated using Kolmogorov-Smirnov (KS) test. Confirmatory factor analysis is then performed to evaluate the power of the statements in explaining hidden variables. Finally, path analysis is used to investigate the relationships between variables in order to validate the research hypotheses.

4.2.1 The normality test of the variables 
Kolmogorov-Smirnov test is used to check the normality of research variables. The statistical hypotheses of this test are as follows:

HO: The variable follows the normal distribution.

$\mathrm{H} 1$ : The variable does not follow the normal distribution.

If the significance level of the test is greater than 0.05 , the null test assumes that the variable is normal and results that the variable is normal and the use of parametric methods is preferred to nonparametric. If the significance level of the test is less than 0.05 , the null test assumes that the variable is normal and results that the variable is not normal and nonparametric methods are preferred to parameter.

Table 4. Kolmogorov-Smirnov test results

\begin{tabular}{|c|c|c|c|c|c|}
\hline Variable & Number & $\begin{array}{c}\text { Test } \\
\text { statistics }\end{array}$ & $\begin{array}{c}\text { Significance } \\
\text { level }\end{array}$ & $\begin{array}{c}\text { Reject / } \\
\text { Accept null } \\
\text { hypotheses }\end{array}$ & $\begin{array}{l}\text { Test } \\
\text { result }\end{array}$ \\
\hline $\begin{array}{l}\text { Operational } \\
\text { risk }\end{array}$ & 384 & .029 & $.901^{\mathrm{e}}$ & $\begin{array}{l}\text { Accept the } \\
\text { null } \\
\text { hypothesis }\end{array}$ & $\begin{array}{c}\text { The } \\
\text { variable } \\
\text { is } \\
\text { normal }\end{array}$ \\
\hline $\begin{array}{l}\text { Financial } \\
\text { risk }\end{array}$ & 384 & .040 & $.564^{\mathrm{e}}$ & $\begin{array}{l}\text { Accept the } \\
\text { null } \\
\text { hypothesis }\end{array}$ & $\begin{array}{c}\text { The } \\
\text { variable } \\
\text { is } \\
\text { normal }\end{array}$ \\
\hline $\begin{array}{l}\text { Hedonic } \\
\text { risk }\end{array}$ & 384 & .041 & $.518^{\mathrm{e}}$ & $\begin{array}{l}\text { Accept the } \\
\text { null } \\
\text { hypothesis }\end{array}$ & $\begin{array}{c}\text { The } \\
\text { variable } \\
\text { is } \\
\text { normal }\end{array}$ \\
\hline Visual risk & 384 & .030 & $.878^{\mathrm{e}}$ & $\begin{array}{l}\text { Accept the } \\
\text { null } \\
\text { hypothesis }\end{array}$ & $\begin{array}{c}\text { The } \\
\text { variable } \\
\text { is } \\
\text { normal }\end{array}$ \\
\hline
\end{tabular}


Given the significant values of the test, which are all greater than 0.05 , the null hypothesis of normality of the sample distribution at $5 \%$ error level is confirmed. This indicates that there is no significant difference between the sample distribution and the normal distribution. Therefore, the distribution of variables is normal and LISREL software is used to implement the structural equation technique.

\subsubsection{Data analysis using structural equation technique}

\subsubsection{Confirmatory factor analysis}

Confirmatory factor analysis is used to verify whether the statements can accurately explain the current variables. Confirmatory factor analysis itself has two parts. In the first part, the factor loadings are estimated and the balls are allowed to stay in the model with a factor load greater than 0.5. In the second step, the significance of the items is assessed using t-test and items with statistics greater than 1.96 are omitted in the model and other items are omitted. In fact, the hypothesis of this t-test is as follows:

HO: The explicit variable cannot explain the current variable.

H1: The explicit variable can explain the current variable.

If the significance test statistic value of the variable is greater than 1.96, the null hypothesis is rejected and the fit of the item is now confirmed. Prior to performing factor analysis, the capability of the data to perform confirmatory factor analysis should be examined. To this end, the adequacy of the number of observations and the appropriateness of the correlation of observations are examined. Sample adequacy is checked using KMO index and if statistical value is more than 0.7 it is determined that the sample number is sufficient according to the number of model parameters.

Bartlett test is used to ensure that observation correlation is appropriate and observation correlation is significant if is less than 0.05 .

Table 5 - Bartlett test and KMO index

\begin{tabular}{c|c}
\hline $\begin{array}{c}\text { Sample } \\
\text { adequacy }\end{array}$ & Correlation evaluation (Bartlett) \\
\hline
\end{tabular}




\begin{tabular}{|c|c|c|c|c|c|}
\hline \multicolumn{2}{|c|}{$\begin{array}{l}\text { measurement } \\
\text { (KMO) }\end{array}$} & \multirow[b]{2}{*}{$\begin{array}{c}\text { Test } \\
\text { statistics }\end{array}$} & \multirow[b]{2}{*}{$\begin{array}{c}\text { Degrees } \\
\text { of } \\
\text { freedom }\end{array}$} & \multirow[b]{2}{*}{$\begin{array}{c}\text { Significance } \\
\text { level }\end{array}$} & \multirow[b]{2}{*}{ Result } \\
\hline Index & Result & & & & \\
\hline 0.761 & $\begin{array}{c}\text { sample } \\
\text { number } \\
\text { is } \\
\text { suitable }\end{array}$ & 718.309 & 325 & 0.000 & $\begin{array}{l}\text { Correlation } \\
\text { is good }\end{array}$ \\
\hline
\end{tabular}

According to the results, confirmatory factor analysis of variables is discussed below. The $\mathrm{Y} 1$ to $\mathrm{Y} 4$ listed in the following diagrams represent operational, financial, Hedonic and visual risks.

Table 6 - Research variables

\begin{tabular}{l|l}
\hline \multicolumn{1}{c|}{$\mathbf{Y}$} & \multicolumn{1}{c}{ Variable } \\
\hline Y1 & Operational risk \\
\hline Y2 & Financial risk \\
\hline Y3 & Hedonic risk \\
\hline Y4 & Visual risk \\
\hline
\end{tabular}

(Continue...) 
Figure 2 - Standard estimation coefficients

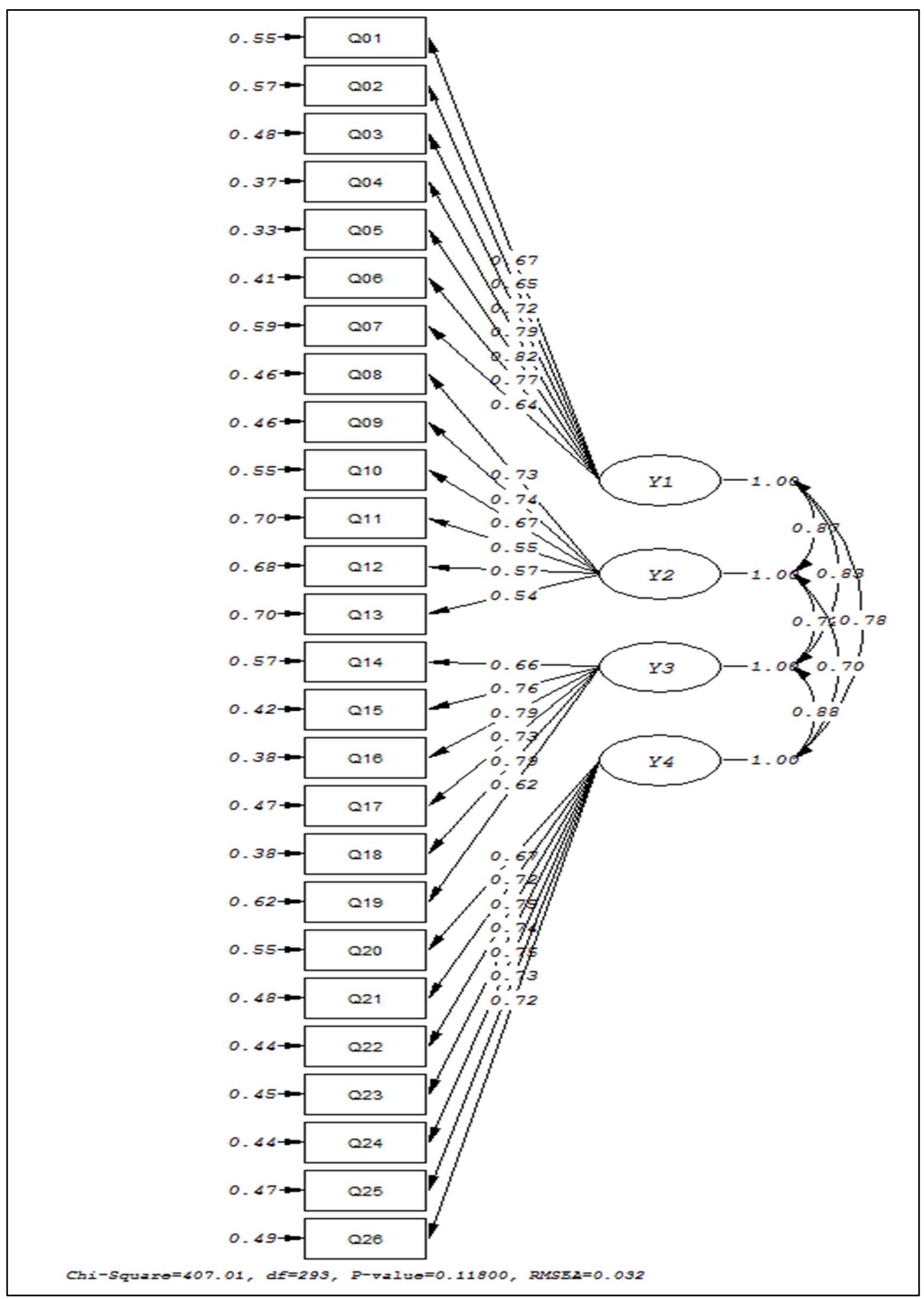

Model factor loadings in the standard solution mode indicate the extent to which each of the variables or items influence the explanation of the variance of the main variable or factor scores. Here is the factor load of numbers between the dotted lines between each 
observer variable (questionnaire questions) and the hidden variables (operational risk, financial risk, hedonic risk, and visual risk).

Figure 3 - Test statistic values $\mathrm{t}$

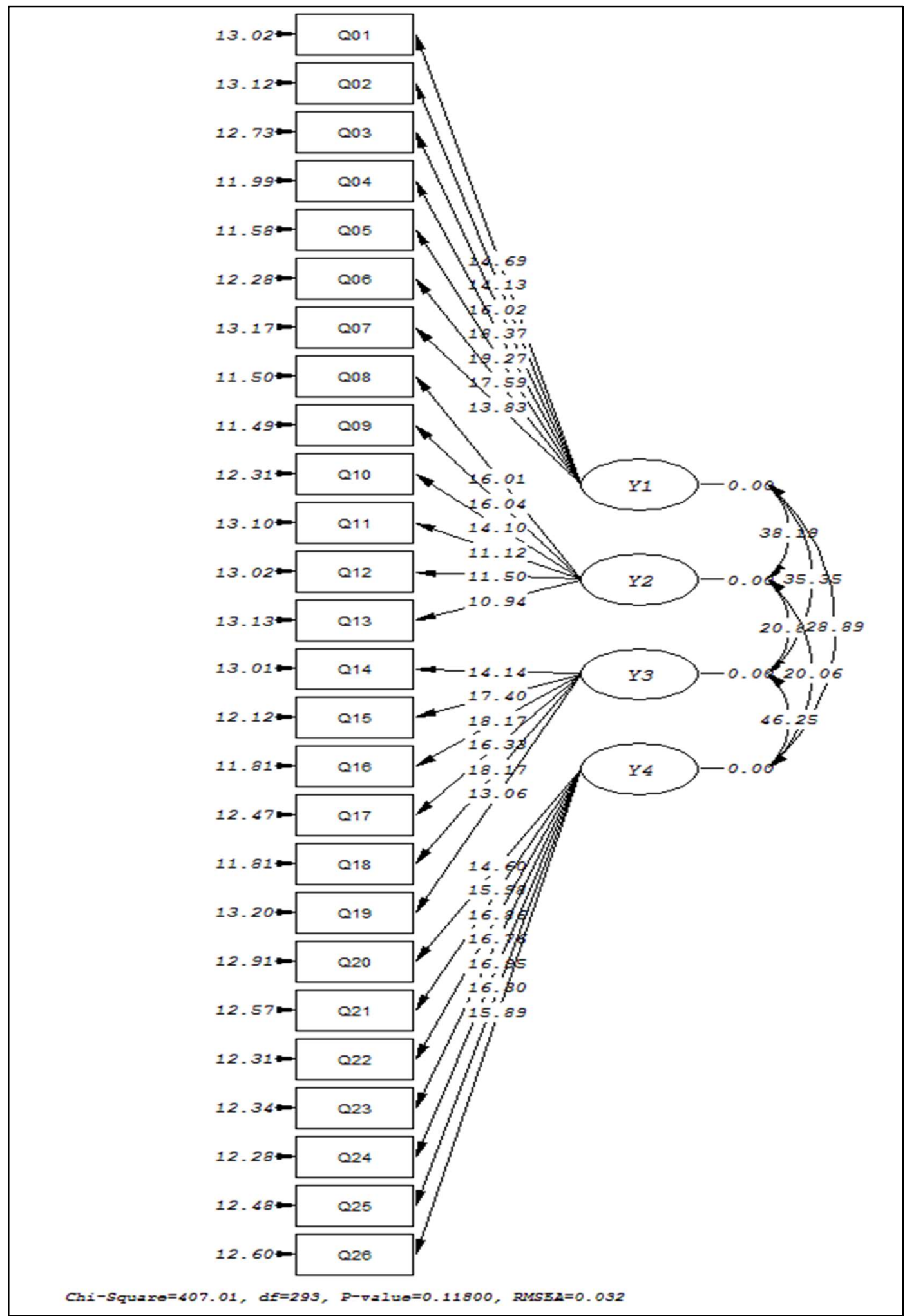


The model in the case of coefficients t or significance state represents the statistical values of $t$ used to judge the significance of the relationships. If the $t$-values are between 1.96 and -1.96 , the coefficients are not significant, leading to the rejection of the research hypotheses and when they are out of range, they are significance. These values are marked in red in non- significance cases. It is necessary to explain that at the 0.05 level of error and the two-way test (normal default) the critical values of the numbers are 1.96 and -1.96 . Confirmatory factor analysis test and standard factor loadings were used to measure the relationship between these variables with their observable variables (questionnaire items) greater than 0.5 and 1.96, respectively. Therefore, items cannot be excluded from the model. The structural model is evaluated on five criteria: likelihood ratio indices $(\chi 2)$, fit index (GFI), and norm fit index $(\mathrm{NFI})$, comparison fit index $(\mathrm{CFI})$ and root mean square error of estimation (RMSEA). The results showed that the chi-square test was not statistically significant because the $p$-value was 0.118 and greater than 0.05 , respectively, which shows that the data model is appropriate.

The GFI, NFI and CFI indices are in the desired range and the RMSEA index is 0.032 indicating good fit of the model.

Table 7 - Goodness of fit indices

\begin{tabular}{l|c|c|c|c|c|c|c|c}
\hline \multicolumn{1}{c|}{ Indices } & CFI & GFI & AGFI & NFI & NNFI & P-value & RMSEA & $\frac{\chi^{\mathbf{2}}}{\boldsymbol{d} \boldsymbol{f}}$ \\
\hline $\begin{array}{l}\text { Acceptable } \\
\text { value }\end{array}$ & $\begin{array}{c}\text { More } \\
\text { than } 0.9\end{array}$ & $\begin{array}{c}\text { More } \\
\text { than } \\
0.8\end{array}$ & $\begin{array}{c}\text { More } \\
\text { than } \\
0.8\end{array}$ & $\begin{array}{c}\text { More } \\
\text { than } \\
0.8\end{array}$ & $\begin{array}{c}\text { More } \\
\text { than } \\
0.8\end{array}$ & $\begin{array}{c}\text { More } \\
\text { than } \\
0.05\end{array}$ & $\begin{array}{c}\text { More } \\
\text { than } 0.05\end{array}$ & $\begin{array}{c}\text { Smaller } \\
\text { than } 3\end{array}$ \\
\hline $\begin{array}{l}\text { Model } \\
\text { value }\end{array}$ & 0.93 & 0.91 & 0.90 & 0.92 & 0.91 & 0.118 & 0.032 & 1.39 \\
\hline
\end{tabular}

4.2.2.2 Fitting the model to observations

After performing confirmatory factor analysis, at this stage, we examine the relationships between research structures. For this purpose, the corresponding model was implemented in LISREL software. In modeling the researcher model, using all the relevant theories of research and information available, deals with the model design and at this stage the model describes the causal relationships between the variables. The relationships 
between variables can be hypotheses that derive causal relationships between the variables present and present from theoretical space. The next step is to test the fit and degree of conformity of these theories with empirical data collected from a given community.

Figure 4 - Standard estimation coefficients of research structural model

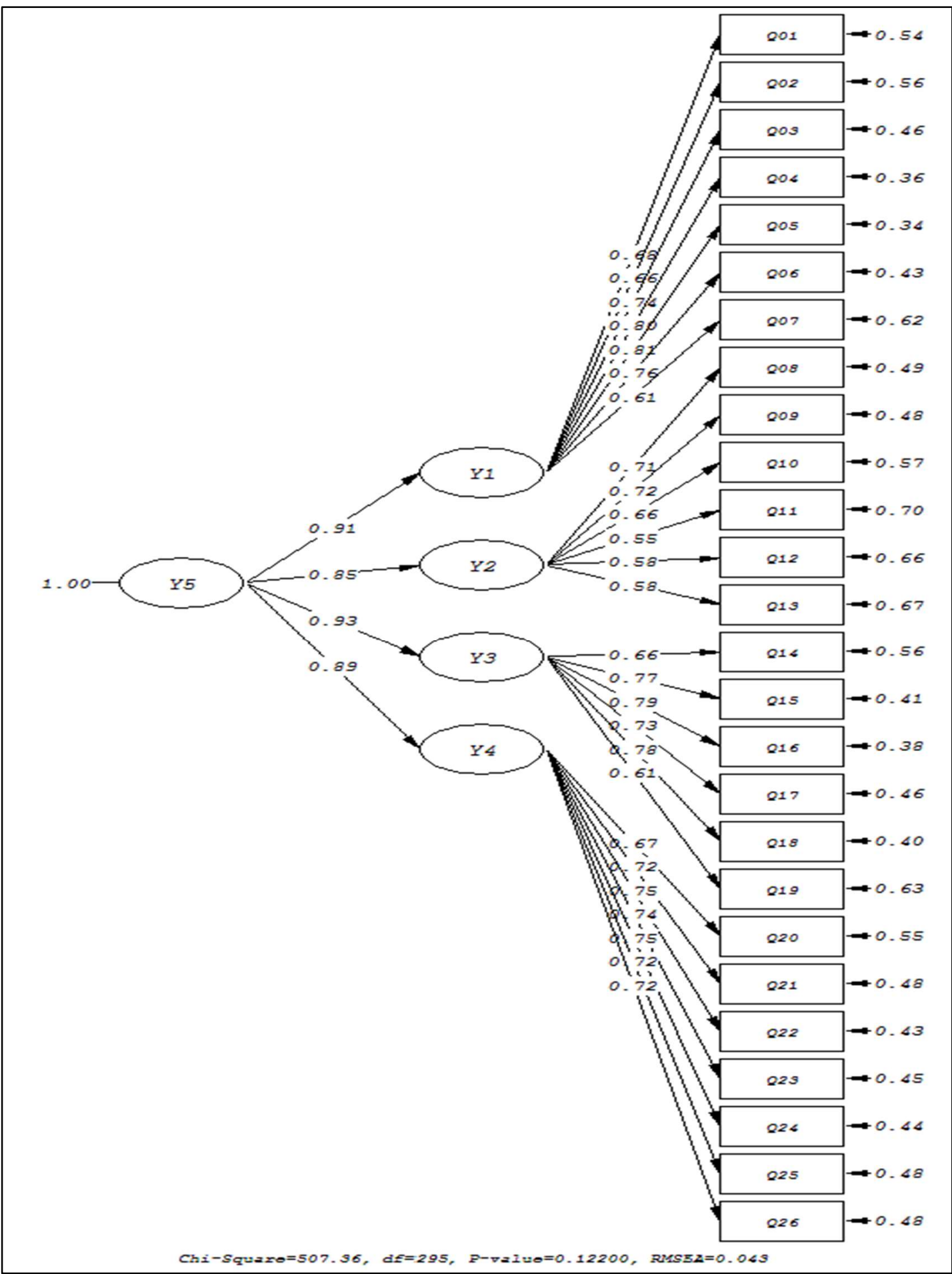


Figure 5 - Test statistic of the structural model of the research

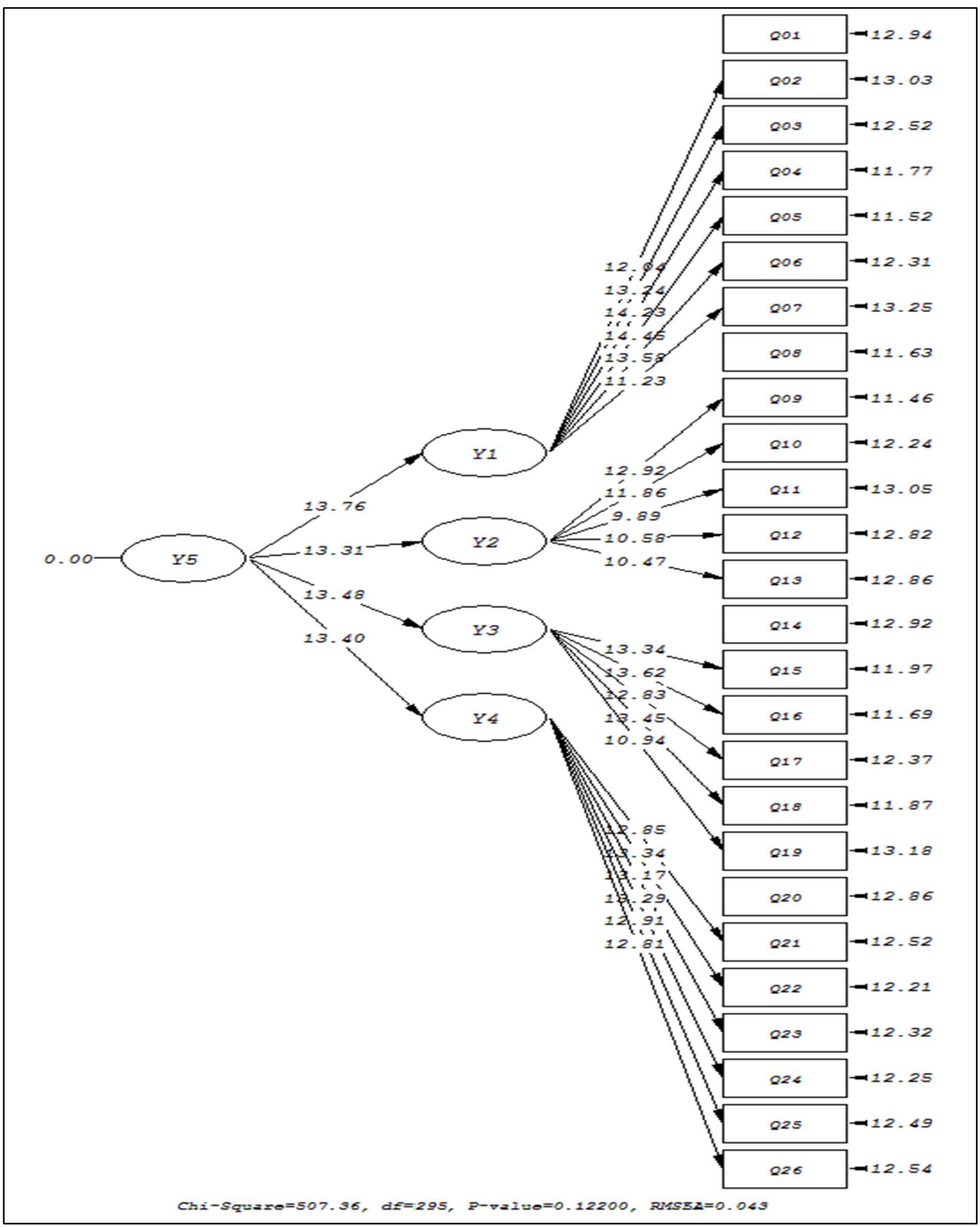

The results of model evaluation criteria showed that the chi-square test was not statistically significant because the p-value was 0.122 and higher than 0.05 , indicating that the model is suitable for the data. The GFI, NFI and CFI indices are in the desired range and the RMSEA index is 0.043 indicating good fit of the model. 
Table 8 - Goodness of fit indices

\begin{tabular}{l|c|c|c|c|c|c|c|c}
\hline \multicolumn{1}{c|}{ Indices } & CFI & GFI & AGFI & NFI & NNFI & P-value & RMSEA & $\frac{\chi^{\mathbf{2}}}{\boldsymbol{d} \boldsymbol{f}}$ \\
\hline $\begin{array}{l}\text { Acceptable } \\
\text { value }\end{array}$ & $\begin{array}{c}\text { More } \\
\text { than } 0.9\end{array}$ & $\begin{array}{c}\text { More } \\
\text { than } \\
0.8\end{array}$ & $\begin{array}{c}\text { More } \\
\text { than } \\
0.8\end{array}$ & $\begin{array}{c}\text { More } \\
\text { than } \\
0.8\end{array}$ & $\begin{array}{c}\text { More } \\
\text { than } \\
0.8\end{array}$ & $\begin{array}{c}\text { More } \\
\text { than } \\
0.05\end{array}$ & $\begin{array}{c}\text { More } \\
\text { than } 0.05\end{array}$ & $\begin{array}{c}\text { Smaller } \\
\text { than } 3\end{array}$ \\
\hline $\begin{array}{l}\text { Model } \\
\text { value }\end{array}$ & 0.94 & 0.91 & 0.90 & 0.93 & 0.91 & 0.122 & 0.043 & 1.72 \\
\hline
\end{tabular}

Summary of the coefficients and test statistic for examining direct hypothesis are presented below.

Table 9 - Summary of coefficients and statistics of direct relationship test

\begin{tabular}{l|l|l|l|l}
\hline No & Hypothesis & $\begin{array}{l}\text { Path } \\
\text { coefficient }\end{array}$ & $\begin{array}{l}\text { T } \\
\text { statistics }\end{array}$ & Result \\
\hline $\begin{array}{l}\text { First } \\
\text { hypothesis }\end{array}$ & $\begin{array}{l}\text { Operational risk is one of the } \\
\text { dimensions of customer's post- } \\
\text { purchase perceived risk in luxury } \\
\text { products. }\end{array}$ & 0.91 & 13.76 & Accepted \\
\hline $\begin{array}{l}\text { Second } \\
\text { hypothesis }\end{array}$ & $\begin{array}{l}\text { Financial risk is one of the } \\
\text { dimensions of customer's post- } \\
\text { purchase perceived risk in luxury } \\
\text { products. }\end{array}$ & 0.85 & 13.31 & Accepted \\
\hline $\begin{array}{l}\text { Third } \\
\text { hypothesis }\end{array}$ & $\begin{array}{l}\text { dimensions of customer's post- } \\
\text { purchase perceived risk in luxury } \\
\text { products. }\end{array}$ & 0.93 & 13.49 & Accepted \\
\hline $\begin{array}{l}\text { Fourth } \\
\text { hypothesis }\end{array}$ & $\begin{array}{l}\text { Visual risk is one of the dimensions } \\
\text { of customer's post-purchase } \\
\text { perceived risk in luxury products. }\end{array}$ & 0.89 & 13.40 & Accepted \\
\hline
\end{tabular}

\section{Discussion and conclusion}

\subsection{Results of inferential analysis}

Operational risk is one of the dimensions of customer's post-purchase perceived risk in luxury products. 
According to the path analysis model and the values presented, the standard path coefficient of operational risk dimension as one of the perceived risk dimensions is 0.91 and (T13.76). Thus, given the $T$ of this path $(T<1.96)$, it can be concluded that with a probability of $95 \%$, the $\mathrm{HO}$ hypothesis is not confirmed and the first hypothesis is confirmed; that is, operational risk is perceived as a customer's post-purchase perceived risk in luxury products. In other words, with a functional risk change unit, the perceived risk after purchasing luxury goods will increase to 0.91 . When studying purchasing behavior as a voluntary behavior, there is no doubt that the outcome of a purchase decision is the need for satisfaction, with positive results expected. So if there are negative consequences in buying situations, it may not be possible to achieve the expected level of satisfaction, because the buyer is at risk in the process of buying and consuming the product. According to the results of the research, operational risk is one of these risks. Reducing the reliability of delivering product promises indicates operational risk. The results of this study are in consistent with the results of researchers such as Chang and Ko(2017) with coefficient of 0.540 and SAEEDI et al. (2014). The researchers also identified performance risk as one of the customer's post-purchase perceived risk in luxury products.

\section{Financial risk is one of the dimensions of customer's post-purchase perceived risk in luxury products.}

According to the path analysis model and the values presented, the standard coefficient of path of financial risk dimension as one of the perceived risk dimensions is 0.85 and (T13.31). Therefore, given the $T$ of this path $(T<1.96)$, it can be concluded that, with a probability of $95 \%$, the $\mathrm{HO}$ hypothesis is not confirmed and the second hypothesis is confirmed, namely the financial risk also cited it as one of the dimensions of customer's postpurchase perceived risk in luxury products. In other words, with a financial risk adjustment unit, the customer's post-purchase perceived risk in luxury products will increase by 0.85 . Risk is the perceived risk that arises from uncertainty in the shopping environment, where consumers perceive the purchase and the serious consequences associated with it as a mistake or an inappropriate decision. When a consumer decides to buy, the risk is the result of making a mistake and the degree of inconvenience. One of these risks is the customer's 
financial risk. Luxury products are generally priced high, if the customer is not sure of the warranty for the product when paying for it, as a result, the financial risk is felt and the purchase rate of the product may decrease. The results of this study are in consistent with the results of researchers such as Chang and Ko (2017) with coefficient of 0.388 and SAEEDI et al. (2014). The researchers also cited financial risk as one of the dimensions of customer's post-purchase perceived risk in luxury products.

\section{Hedonic risk is one of the dimensions of customer's post-purchase perceived risk in luxury products.}

According to the path analysis model and the values presented, the standard coefficient of path of the hedonic risk dimension as one of the perceived risk dimensions is 0.93 and $(\mathrm{T} 13.49) ; \mathrm{T})$. It can be concluded that, with a probability of $95 \%$, the $\mathrm{H} 0$ hypothesis is unverified and the third hypothesis is confirmed, that is, the risk-taker is the customer's post-purchase perceived risk in luxury products. In other words, with a hedonic risk shift unit, the perceived risk of buying luxury goods will increase by 0.93 . Consumer behavior is significantly risk-related, so that any action it may have has deleterious consequences. Today, risk management is a professional process and system whose main purpose is to improve the quality of decisions at all levels of customer orientation. This can identify, mitigate, and ultimately increase the company's sales risk. According to research results, one of these risks, which can influence customers' purchasing decisions, is hedonic -risk. This means that the customer is afraid that the luxury product will not be a luxury for them. The results of this study are consistent with the results of researchers such as CHANG AND KO (2017) with coefficient of 0.642 and SAEEDI et al. (2014). The researchers also cited hedonic risk as one of the customer's post-purchase perceived risk in luxury products.

\section{Visual risk is one of the dimensions of customer's post-purchase perceived risk in luxury products.}

According to the path analysis model and the values presented, the standard coefficient of path of the visual risk dimension as one of the perceived risk dimensions is 0.89 and ( 13.40$)$. Therefore, given the $T$ of this path $(T<1.96)$, it can be concluded that, 
with a probability of $95 \%$, the hypothesis $\mathrm{HO}$ is not confirmed and the fourth hypothesis is confirmed; that is, visual risk is the perceived risk dimension of buying luxury goods. In other words, with a visual risk change unit, the customer's post-purchase perceived risk in luxury products will increase to 0.89 . According to existing theories, if customers have a good brand image and lower the risk of purchasing, they can increase the amount of purchase by customers and achieve higher profitability. One of the dimensions of perceived risk is visual risk. That is to say, by purchasing a luxury product, the customer perceives it as superior and distinctive in the minds of colleagues, friends and acquaintances. Now that the product has been purchased, if this goal is not met, consequences such as decreased customer satisfaction, misunderstanding about the brand and product or even brand abandonment by the customer will be realized. Therefore, it is necessary to minimize the identified risks. The results of this study are consistent with the results of researchers such as CHANG AND KO (2017) with coefficient of 0.461 and Saeedi et al. (2014). The researchers also cited visual risk as one of the dimensions of perceived risk after purchasing luxury goods. Finally, the top management of luxury product companies is advised to ensure that their promises are fulfilled by documenting their promises to customers in the organizational documentation and periodically following up on the promises made. These promises can include postpurchase service, discounts on future purchases and more.

\section{References}

Chang, E. C., \& Tseng, Y. F. Research note: E-store image, perceived value and perceived risk. Journal of business research, 66(7), 864-870, 2013.

Chang, Y., \& Ko, Y. J. Consumers' perceived post purchase risk in luxury services. International Journal of Hospitality Management, 61, 94-106, 2017.

Chen, C. Perceived risk, usage frequency of mobile banking services. Managing Service Quality: An International Journal, 23 (5), 410-436, 2013.

Feiz, Davood and Hossein Esmaili. Investigating the perceived trust and risk position in predicting customer intention in e-commerce, Information Technology and Economic Jihad Conference, Kazerun, Kazerun Higher Education Complex, 2011.

Grewal, D., Iyer, G.R., Gotlieb, J., Levy, M. Developing a deeper understandingof postpurchase perceived risk and behavioral intentions in a service setting. J.Acad. Market. Sci. 35 
(2), 250-258, 2007.

Heidarzadeh, Kambiz, Varamini, Masoumeh, Babazadeh Baie, Mohammad, Hosseini Amiri, Seyyed Mahmood. Investigate the impact of customer satisfaction, perceived confidence, perceived risk, and customer awareness of the product on the willingness to buy a new product. Quarterly Journal of Management Development, (Special Letter), 11-18, 2016.

Laroche, M., McDougall, G. H., Bergeron, J., \& Yang, Z. Exploring how intangibility affects perceived risk. Journal of Service Research, 6 (4), 373-389, 2004.

Lee, J.H., Hwang, J. Luxury marketing: the influences of psychological anddemographic characteristics on attitudes toward luxury restaurants. Int. J.Hosp. Manage. 30, 658-669, 2011.

Saeeda Ardakani, Saeed, Jahanbazi, Neda. Influence of store image on customer intention to buy: Trust and perceived risk as moderating variables. Modern Marketing Research, 5 (2), 53-72, 2015.

Saeedi, Ghazaleh; Alireza Soloukdar and Mandan Momeni. Investigating the Impact of Perceived Risk on Intention to Use Mobile Banking Services, First National Marketing Research Conference, Narkish Information Institute, Tehran, 2014.

Sayahzadeh Kakhki, Ehsan. Investigating the Impact of Perceived Product Quality, Price and Perceived Risk on Customer Value and Customer Purchase, First National Future Research, Management and Development Conference, Tehran, Iran, 2014.

Sun, J. How risky are services? An empirical investigation on theantecedents and consequences of perceived risk for hotel service. Int. J. Hosp.Manage. 37, 171-179, 2014.

Tynan, C., McKechnie, S., \& Chhuon, C. Co-creating value for luxury brands. Journal of Business Research, 63 (11), 1156-1163, 2010.

Varamin, Masoumeh and Kambiz Heidarzadeh Henzai. Which of the perceived nutritional risk dimensions (psychological, functional, and physical) are more and which consumers are less interested in buying a new product? (Experimental Study) (Experimental Study), Second National Conference on Marketing Research, Tehran, Narkish Information Institute, 2015.

Yang, W., \& Mattila, A. S. The role of tie strength on consumer dissatisfaction responses. International Journal of Hospitality Management, 12(4), 146-161, 2012. 